\title{
Incidence of Girl-Child Defilement in Ugbighokho Community South-South Nigeria: The Way Forward
}

\author{
Osamuyi Aghasomwan Bello
}

\author{
Department of Social Work, \\ Faculty of Social Sciences, \\ University of Benin, Benin City, Nigeria \\ Isoken Linda Osunde \\ Department of Sociology and Anthropology, \\ Faculty of Social Sciences, \\ University of Benin, \\ Benin City, Nigeria \\ Corresponding Author
}

DOI: https://doi.org/10.36941/mjss-2022-0oo2

Abstract

This study explores the incidence of girl-child defilement in Ugbighokho Community, South-south Nigeria. The study was guided by the ecological system perspective and the play therapy. The study pointed out some of the socio-economic factors that causes the girl-child defilement which includes, poverty, ignorance, gender inequality and the nature of child's residence or environment where the child lives. The sample size of this study was 400 using the simple random sampling technique. The cross sectional survey method was adopted for this study. The study established that poverty was the main cause of the girl-child defilement in Ugbighokho Community. The study further revealed that social tie was the main cause for under-reporting of girl-child defilement which in turn has a far-reaching effect on the victim(s). The study therefore recommends poverty alleviation programmes as a means of generating income activities for caregivers in order to prevent them from being compromised by offenders.

Keywords: Child defilement, Child protection, Sexual abuse, Sexual assault, Sexual grooming

\section{Introduction}

Girl-child defilement according to section 218 of the Nigeria Criminal Code stipulates that "any person who has unlawful carnal knowledge of a girl under the age of 13 years is guilty of felony and liable to imprisonment for life, with or without whipping”. Globally, girl-child defilement is a serious problem as it cut across all facets of human societies. In many countries of the world and Nigeria inclusive, the incidence of child sexual abuse is often been ignored or denied as most people tends to accept some acts as a belief system in other to preserve their family (Schwartz-Kenny, McCauley and Epstein, 2001). In previous years, it was difficult to believe and accept the axiom that some parents or 
caregivers were involved in the sexual molestation and abuse of their children. Girl-child defilement is a human rights issue, and human rights are fundamental to values of dignity, equality, nondiscrimination and non-interference. It is one of the most prevalent forms of child abuse (Heise, Ellsberg and Gotle, 2002). This form of abuse in children if not curbed has the tendency of causing unwanted pregnancies that has the potentiality of increasing the risk of sexually transmitted infections to the victims by the defiler. The incidence of this form of child abuse has been linked to numerous kinds of immediate and long-term physical and psychological injury to young females. In light of mounting evidence of its varied and harmful immediate and secondary effects, girl-child defilement is increasingly being recognized not only as an issue of human rights but also as a serious public health concern to the victims (World Health Organization, 2002).

According to Pinheiro (2006), child sexual abuse occurs in places normally considered safe such as the home and school environments, by perpetrators especially those who are known and trusted by the child or those who have authority over them. He stated that adolescent females are most likely to be sexually abused by persons known to them, who are usually male adult or older family member, family friend or someone who has authority over the child. He further posited that children who live in low-income regions of the world are usually exposed to some level of insecurity, which makes them to be more vulnerable members of the society. Therefore, eliminating sexual abuse and exploitation and all forms of gender-based violence is recognized as crucial to economic and social development. Langan and Wolf (2013) asserted that close relatives and family members are usually the culprits of the cases of child sexual abuse in Nigeria. They further reported that $40 \%$ of the global sexual perpetrators were juveniles who were below the age of 18 years. More so, gang rapes were commonly committed by adolescent males who were between the age of 7-15 years old thereby suggesting that girl-child defilement constitutes a sizeable and possibly underreported problem in Nigeria.

Furthermore, defilement investigations are shoddy and most times unreported or with dark figures in Nigeria due to the fact that they are usually committed by close relatives or those known to the victim(s). Meanwhile, Heise (2002) proposed an ecological framework which suggests that the girl-child defilement arises from the interplay of some social and economic factors. This framework draws on the cross-cultural literature which identifies specific factors associated with female sexual abuse at each level of the social system. There is therefore need to properly understand how the various factors are interrelated and how they interact with one another in influencing the female's risk of defilement particularly in rural areas, suburbs as well as in the urban centers as this is the focal point of this study.

\section{Statement of the Problem}

Girl-child defilement remains one of the heinous and abhorrent crimes in society. it is a debilitating experience for children who are victimized with negative social, psychological, educational and physical health outcomes that is not only having detrimental effects on the victim(s) but also in their families and the society they belong (Madu, Ndom, and Ramashia, 2010; Collin-Vezina, Daigneault, and Hebert 2013; WHO, 2014). Meanwhile, Hillis, Mercy, Amobi, and Kress (2016) reported that within the year 2013 to 2014 , about one to two billion children particularly females were exposed to sexual violence globally.

In other to curb the incidence girl-child defilement as a social ill in the society, the causes as well as the effects on the victims should be adequately understood. This is so as this incident is gravely affecting most children in Nigeria particularly those who are involved in hawking, street trading and other forms of child labour as they are often being defiled by adults. However, the survival, development and protection of the girl-child, hangs in balance as more and more of these children are been defiled daily at an alarming rate. However, the increase in the rate of pedophiles in Nigeria often leads to the devastation of the female children as they are mentally, physically, emotionally and psychologically stressed as the see the perpetrators of this evil acts left without been 
punished due to the relaxed nature of the law on sexual defilement of female children. This therefore makes it to be impossible to them to love themselves and also loose fate in the country where they belong. Thus, the human rights of female children in Nigeria, even when protected on paper, are violated in practice.

Despite the harsh sentences imposed on girl-child defilers, more female children are still being defiled; this invariably implies that the female children are living in very difficult circumstances, as the environment in which the children are growing up in, is no longer safe, and this consequently impact negatively on their development. The other source of concern is that despite adequate sensitization campaigns conducted against girl-child defilement, the existence of the relevant laws, expanding police force, growing judiciary, civil society advocacy on child rights, and parents plus local community authorities, all arrayed against girl-child defilement, appeared not to be yielding positive results as evidenced by the marked increase in the defilement of the girl-child.

Despite the numerous studies have been undertaken to determine the causes and effects of girl child defilement, not much have been done to know the reasons for the dark figures of this heinous crime. Despite all the measures that have been put in place, the issues of defilement of the girl-child is still on the increase. In spite of this, no empirical study has been conducted to caption the role of social workers and Criminologist in curbing girl-child defilement in Ugbighokho Community, Edo State and this creates a literature gap which this study intends to fill.

\section{Literature Review}

This part reviewed various literatures related to this study.

\subsection{Unreported cases of girl-child defilement}

In Nigeria, child sexual abuse is an offence under several sections of chapter 21 of the country's criminal code as the age of consent is 18. United Nations International Children's Emergency Fund reported in 2015 that one in every four girls in Nigeria usually experienced sexual violence before the age of 18 . According to a survey by Positive Action for Treatment Access, over 31.4 percent of girls agreed that their first sexual encounter was rape or forced sex of some kind. Conversely, a study conducted in a medical facility in Abuja, Nigeria by Folake (2014) found out that one hundred and thirty-one (131) cases of female defilement occurred for a period of over three-year. This therefore suggests that like some other cases affecting children such as child neglect, child molestation amongst others, child defilement on the other hand, constitutes a sizeable and possibly one of the highly underreported problem in Nigeria.

A recent study conducted by World Health Organization, (1999) from nineteen countries of the world, including Nigeria, South Africa, Sweden, Dominican Republic amongst others revealed that the rates of child sexual abuse ranges from 7 percent to 34 percent for girls and from 3 to 29 percent for boys. More so, a similar study conducted by the United Nations in 2006 based on global violence against children estimated that about 150 million girls of the world population are sexually abused each year.

The study conducted by Terry and Tallon (2010), illustrated that about $36 \%$ of girls in the world have suffered child sexual defilement. In a similar vein, Langan and Wolf (2013) stated that, there are reported cases of child sexual abuse which amount to 50\%. In another study conducted by Nzewi (2013) in the Eastern part of Nigeria, the result shows that $60 \%$ of child defilement cases occurred in female children who were below 12 years of age as they were severely exposed to the act of seduction, stimulation by older adults. More so, Tukur, Omale, and Abubakar (2007) conducted a retrospective study on the incidence of child sexual abuse in the North Western Nigerian. The result of the study shows that there is a low rate of the incidence of child sexual abuse even though all but one of which were children below the age of 17 years.

In addition, children have also been reported as some of the offenders of the cases of child 
defilement in Nigeria. A study conducted by Langan and Wolf (2013) found out that $40 \%$ of sex perpetrators globally were caused by adolescents who were less than 18 years old. He further stated that in Nigeria, those who are in the age of 7-15 years were found to be the main culprits of gang rape which is a common form of girl child defilement. A recent survey conducted in the North Central part of Nigeria in a one year hospital base report by Abdulkadir, Musa, Umar, Musa, Jimoh, and Aliyu Na'uzo, (2011), revealed that forty-one adolescents were involved in child defilement. Adetayo (2005) reported that in the first quarter of 2015, about 513 people were in police custody in connection with 423 cases of female defilement in Lagos State, Nigeria. The report revealed that of the total number of suspects, 134 were women while the others were men. A similar study conducted by Biodun (2009) in Ibadan, Nigeria, showed that $15 \%$ of female adolescents experienced forceful sexual penetration by the defilers. There is a problem of inappropriate records of incidences of girl child defilement as most cases are often underreported because of the social stigmas that are often associated with it.

Furthermore, a recent survey also conducted by Agams (2013) also reveals that despite the large population of approximately 20 million in Lagos State, Nigeria in the year 2011, out of 283 child defilement cases reported, only 10 were duly prosecuted and convicted appropriately. Further studies have also reveal that as much as over $84 \%$ of females have experienced the incidence of sexual assault or childhood defilement with only less than $10 \%$ convicted. This assertion was supported by WHO, (2002); Greco and Dawgert, (2007) who stated that those who lack power of some forms in the society, those living in poverty, and those who are unlikely to report defilement cases constitute the bulk population of female defilement cases. Lastly, a pilot study on the review of the incidence of child defilement case based on police report in Ibadan, Nigeria by Ikechebelu, (2008) showed that the perpetrators of this heinous crime were mainly males as $32.5 \%$ were acquaintances, $21.6 \%$ were strangers, and $16.1 \%$ were neighbours of the victims. The study further revealed that there were various complex and multi-faceted reasons for the non-reporting of the cases of child defilement as these includes but not limited to: the relationship between the victim (defiled) and the defiler, the age of the victim at the time of defilement, how severe the abuse is, amongst others. The study also revealed that the girl-child is more likely to be abused than boy-child and in most cases when the defiler is a close relative; there are fewer tendencies that the cases of abuse will be reported. This is so as some may choose not to report due to social stigma associated with defilement, fear of negative consequence of disclosure, shame or ridicule, and problem due to lack of confidentiality of the police or the health care professionals. There is no gainsaying as sexual abuse perpetrators may come from all works of life, irrespective of whether they are rich or poor, young or old, educated or uneducated, religious or non-religious as the offender may also be an individual who occupy a seat of authority who may be highly reverend, trusted and respected by the victim or their caregivers. There is a general acknowledgment of the incidence of girl-child defilement in all countries of the world even though there are limited statistics to show the prevalence of the incident rate. The defilement of the girl-child is of global concern as it violates the inalienable rights of the girl-child which further expose them to dangers and other forms of abuse. In Nigeria, this situation is worrisome as majority of the victims who are labouring are often been defiled by adults. This is highly a condemnable act and members of the society and the nation in general must rise to eradicate this despicable act.

This paper was informed by the ecological system perspective and the play therapy. The ecological system perspective has its root from the family system theory which posits that individuals are to be considered as members of the family. This theory emphasizes the principle of individual's resolution to the presenting problem that could be from within (self) or from the external environment (Kantrowitz and Okun, 2015). This theory also focuses on the mutual relationship between the individual and their environment. According to Wilson and Ryan (2006), play therapy on the other hand is a structured approach of intervening with children within a therapeutic relationship. In the application of this theory, the social worker therefore acts as a therapist, who creates a suitable environment for children to explore and express their thoughts, feelings, and experiences through play. The focus of this intervention model is to evaluate the strength and weaknesses of the child in accordance with their developmental stages. This model is more 
preferable for eliciting information from children because play is seen as a natural medium of expression for children. This therefore makes it crucial for the social worker or healthcare professional to have adequate knowledge on the skills, and techniques to implore in other to effectively manage and assist the child concerned.

The above perspective and theory are concerned with the wellbeing and free choice of all individuals, especially people made vulnerable due to poverty, stigma, marginalization, abuse or violence. These theories will help to understand and protect the girl-child from sexual exploitation with or without consent in the society that it is the violation of rights that makes female children to be defiled by whatever societal norms and cultural practices of the people within a given society. These theories will also help to illuminate the study because it helped to identify the daily challenges faced by female children which affect their daily survival in the environment, they live in.

\subsection{Objective of study}

The main objective of the study is to examine the role of social workers/criminologist in curbing the girl child defilement in Benin metropolis.

The specific objectives are to:

1. Explore the socio-cultural factors responsible for girl-child defilement in Ugbighokho Community.

2. Find out why the incidence of girl-child defilement is under-reported to relevant authorities in Ugbighokho Community.

3. Determine the effect of girl-child defilement on the victims in Ugbighokho Community.

\section{Methodology}

The study adopted a descriptive survey research design. The descriptive survey design is considered most suitable for the study because it permits the collection of original data from the respondents themselves. The quantitative and qualitative method was adopted as the method of data collection using both the semi-structured questionnaire and the focus group discussion respectively.

The population of this study were all females who are 18 years and below and are resident within the selected area. Arising from the 2006 population census figure of 339,899 and the annual growth rate for Egor Local Government (2.74\%) (National Population Commission, 2006). Therefore, the projected population for Egor Local Government in the year 2020 was 492,854. Four hundred respondents were selected as the sample size of this study which was drawn from the population using the Taro Yamane mathematical model. The simple random sampling technique was adopted for the study. The data collected was analyzed using the SPSS version 20.0. The results of the analyses are below.

\section{Results and Discussion of Findings}

Table 1: Socio-demographic Characteristics of Participants

\begin{tabular}{|l|l|c|c|}
\hline Socio-demographic characteristics & Responses & Frequency & Percentage \\
\hline Gender & Females & 400 & 100 \\
\hline Marital Status & Single & 388 & 97 \\
& Married & 8 & 2 \\
& Others & 4 & 1 \\
\hline Age & $7-9$ & 87 & 21.8 \\
& $10-12$ & 123 & 30.8 \\
& $13-15$ & 125 & 31.3 \\
& $16-$ Below 18 & 60 & 15 \\
& 18 and Above & 5 & 1.3 \\
\hline
\end{tabular}




\begin{tabular}{|l|l|c|c|}
\hline Socio-demographic characteristics & Responses & Frequency & Percentage \\
\hline Educational qualifications & No formal education & 36 & 9 \\
& Primary Education & 171 & 42.8 \\
& Secondary Education & 189 & 47.3 \\
& Tertiary Education & 4 & 1 \\
\hline Religious Affiliation & Christianity & 351 & 87.8 \\
& Islam & 23 & 5.8 \\
& ATR & 26 & 6.5 \\
\hline Ethnic group & Benins & $\mathbf{2 2 5}$ & 56.3 \\
& Hausas & 29 & 7.3 \\
& Igbos & 51 & 12.8 \\
& Yorubas & 63 & 15.8 \\
\hline Total & Others & 32 & 8 \\
\hline
\end{tabular}

Source: Field work, 2021

Table 1 above reveals the marital status of participants, in which 388 participants representing $97 \%$ were single, 8 participants representing $2 \%$ were married, and 4 participants representing $1 \%$ were others. From the preceding, it was clearly observed that majority of the participants were single as only $2 \%$ of females were married. Then the respondent's age shows that 7-9 years were 87 participants representing 21.8\%, 10-12 years were 123 participants representing 30.8\%, 13-15 years were 125 participants representing $31.3 \%$ were 16 -below 18 years while 5 participants representing $1.3 \%$ were 18 years and above. From the analysis above it can be deduced that majority of the participants were within the age of 10-12 and 1315years. While the educational qualifications of the respondents were subdivided into four categories which were no-formal education, Primary education, secondary education and tertiary education. Out of the 400 participants, $36(9 \%)$ had no formal education, $171(42.8 \%)$ had primary education, $189(47.3 \%)$ had secondary education and $4(1 \%)$ had tertiary education. From the foregoing, it is gleaning that majority of the participants had primary and secondary education.

Furthermore, the religious affiliation of the respondents also reveals that 351 participants representing $87.8 \%$ were Christians while 23 participants representing $5.8 \%$ were Muslims and 26 participants were Pagans. The above data therefore shows that majority of the respondents were Christians this can be attributed to the fact that Ugbighokho community is a Christian dominated area. Lastly, the ethnic groups of the respondents show that 225 participants representing 56.3\% were Benin, 29 participants representing $7.3 \%$ were Igbo, 51 participants representing $12.8 \%$ were Yoruba, 63 participants representing $15.8 \%$ were Hausa and 32 participants representing $8 \%$ represented other ethnic groups.

Research Question One: What socio-cultural factors responsible for girl-child defilement in Ugbighokho Community?

Table 2: Socio-cultural factors responsible for girl-child defilement in Ugbighokho Community

\begin{tabular}{|l|l|c|c|}
\hline Variable & Responses & Frequency & Percentage \\
\hline Do you think that female child defilement is & Yes & 256 & 64 \\
a serious issue in your locality? & No & 89 & 22.3 \\
& I don't know & 55 & 13.8 \\
\hline Who are those that mainly defile the girl-child & Father & 36 & 9 \\
in this area? & Close relatives & 145 & 36.3 \\
& Neighbours & 158 & 39.5 \\
& Teachers & 61 & 15.3 \\
\hline What are the socio-economic factors that & Poverty & 122 & 30.5 \\
promote girl-child defilement in your locality? & Ignorance & 59 & 14.8 \\
& Gender inequality & 87 & 21.8 \\
& Nature of child's residence & 132 & 33 \\
\hline Total & & $\mathbf{4 0 0}$ & $\mathbf{1 0 0}$ \\
\hline
\end{tabular}

Source: Field work, 2021 
Table 2 above shows the socio-cultural factors that are responsible for girl-child defilement in Ugbighokho Community. Three research questions were raised. Firstly, the question on if the defilement of the girl-child was a serious issue in Ugbighokho Community. From the above analysis, 256 participants representing 64\% agreed that girl-child defilement is a serious issue in Ugbighokho Community, 89 participants representing $\mathbf{2 2 . 3} \%$ disagreed that girl-child defilement is a serious issue in Ugbighokho Community. Meanwhile, 55 participants representing 13.8\% were undecided in their response. Secondly, responses on those that mainly defile the girl-child in Ugbighokho Community, statistics shows that out of 400 participants, 36(9\%) stated that the father of the child is responsible for girl-child defilement, $145(36.3 \%)$ stated that the defilers of females were their close relatives, 158 $(39.5 \%)$ stated that the defilers of the girl-child were neighbours who lives within the neighbourhood and lastly, 61(15.3\%) stated that the teachers to the girl-child is the main defiler in Ugbighokho Community. Moreover, on the question on the factors that promote girl-child defilement in Ugbighokho Community, 122(30.5\%) show that poverty was the major cause of the girl child defilement Ugbighokho Community, 59(14.8\%) agreed that ignorance was the major cause of the girl child defilement in Ugbighokho Community, 87(21.8\%) agreed that gender inequality was the major cause of girl child defilement and 132(33\%) agreed that the nature of child's residence was the major cause of the girl child defilement in Ugbighokho Community.

Results from the focus group discussion from some participants further corroborate with the above result and stated thus:

"Girl-child defilement is a serious problem in this Community. In fact, rape and child sexual abuse occur here rapidly. Majority of the adolescents in this community are at their own liberty to visit those within their neighbourhood. Therefore, if one goes out to the neighbour's apartment who apparently may be a single male and does not return home quickly with the assumption that the child is preoccupied with movies or a TV programme, the parents do not really care because their (parents) live in one room apartment and may want to quickly settle their private affairs before the child returns". (FGD1/ Security personnel/ Married/2021)

Another participant stated as follows:

"I was sexually abused by my cousin who came to spend the holiday with us some years ago. At first, he started by telling me that we should always shower together when my parents were not at home. I was 13 years old then while he was about 17 years old. Apart from me, some children in this Community have been sexually abused especially when they go out hawking for their parents. Most often, before they return home, they are usually being lured by neighbours particularly the gangsters around, and they are defiled". (FGD2/17 years old/ Tertiary Education/Single/2021)

Another participant also stated thus:

The major problem faced by most parents is that they have too many children that they can adequately cater for to the extent that some of them cannot even provide food for their children needless to say the other basic needs for their children. These often make the defilers to explore such opportunities by making provision for such needs and at times, they use this opportunity to lure these innocent children with money; and with time, they defile them.(FGD3/38years old/ Security personnel/2021)

From the foregoing, it is evident that girl-child defilement is a serious problem in Ugbighokho Community as majority of the participants stated that the main defilers of females were those around their neighbourhoods and the victim's close relatives. The above analysis in table 2 also revealed that the nature of the child's environment as well as poverty were the chief socio-cultural factors responsible for the defilement if females in Ugbighokho Community. This finding is in agreement with the report of World Health Organization, (2002) which states that poverty is one of the key of vulnerabilities of individuals to crime.

Research Question Two: Why are the incidences of girl child defilement under-reported to 
relevant authorities in Ugbighokho Community?

Table 4: Reasons for under-reporting of incidence of girl child defilement in Ugbighokho Community

\begin{tabular}{|l|l|c|c|}
\hline Variables & Responses & Frequency & Percentage \\
\hline Would you love to see a defiler that you & Yes & 103 & 25.8 \\
know been arrested by the police? & No & 297 & 74.3 \\
\hline Would you prefer a defiler who is a close & Yes & 177 & 44.3 \\
relative to be prosecuted and sent to & No & 223 & 55.8 \\
jail if found guilty? & & 124 & 31 \\
\hline Why are the cases of female defilement & Discrimination & 100 & 25 \\
in Ugbighokho Community under-reported & Perpetrators are close relatives & 176 & 44 \\
to relevant agencies? & Poverty of parents/ Guardians & 176 \\
\hline Total & & $\mathbf{4 0 0}$ & $\mathbf{1 0 0}$ \\
\hline
\end{tabular}

Source: Field work, 2021

The table 4 above shows the responses of participants on the reasons for the under-reporting of cases of girl child defilement in Ugbighokho Community. Three vital questions were raised to explain the above questions. Firstly, participants were asked if they would love to see a defiler that is been known by them to be arrested by the police. Out of 400 participants, $103(25.8 \%)$ agreed that they prefer that a defiler known to them should be arrested by the police while $297(74.3 \%)$ disagreed that they will not prefer that a defiler known to them should not be arrested by the police. On the question whether participants would prefer a defiler who is a close relative to be prosecuted and sent to jail if found guilty. Out of 400 participants, $177(44.3 \%)$ agreed that they would prefer a defiler who is a close relative to be prosecuted and sent to jail if found guilty while $223(55.8 \%)$ disagreed that they would not prefer a defiler who is a close relative to be prosecuted and sent to jail if found guilty. On why the cases of female defilement in Ugbighokho Community are under-reported to relevant agencies, $124(21 \%)$ stated that discrimination and stigmatization was the reason for the under reporting of cases of defilement in Ugbighokho Community, 100(25\%) stated that perpetrators are close relatives was the reason for the under reporting of cases of defilement in Ugbighokho Community and $176(44 \%)$ stated that poverty of parents/guardians was the reason for the under reporting of cases of defilement in Ugbighokho Community.

In supporting the above position, some research focus group participants declared:

I actually felt very bad when the incident happened to me but I didn't know how my aunt would handle the situation. This even made me to be more scared and worried that I could not even concentrate at that point in time. The case was not reported to the police or any relevant agency because l was been defiled by my uncle. When I finally told her, she warned that I should not disclose it to anyone because my uncle was the 'breadwinner' in the family. She told me that if the case is reported that I will suffer, and that I will not get anybody to feed and pay my school fees. (FGD4/16 years/secondary education/2021)

Another participant added:

In this community like in others, families feel shy to report cases of defilement, this could be due to the consequences when the victims are found guilty or due to poverty. At one time a landlord defiled a 13year-old girl and instructed those who knew about it not to talk about it. They were afraid to report the matter to relevant agencies because if they do, the landlord would quit them from the apartment. The family ended up collecting money from him without reporting the case.

(FGD 3 / Police officer/ married/2021)

The findings above revealed that poverty is the major reason for the underreporting of the 
incidence of girl-child defilement in Ugbighokho Community South-south, Nigeria. This is so as majority of the respondents agreed that poverty of their parents or guidance accounts for the problem of underreporting of the girl-child defilement. In addition, majority of the respondents are of the opinion that they would prefer to see their defilers who are either their close relatives or those who are known to them walk freely rather than been persecuted by relevant agencies. This is so as the caregivers (parents/guidance) may refuse to report cases of defilement of their ward(s) because of the close relationship they have with the defiler or due to their economic dependency on the defiler.

Research Question Three: What are the effects of girl-child defilement on the victims in Ugbighokho Community?

Table 3: Effect of female defilement on the girl-child in Ugbighokho Community

\begin{tabular}{|l|l|c|c|}
\hline Variables & Responses & Frequency & Percentage \\
\hline Do you agree that female defilement & Yes & 293 & 73.3 \\
have negative effects on the girl child? & No & 33 & 8.3 \\
& I don't know & 74 & 18.5 \\
\hline What is the effect of female child & Trauma & 55 & 13.8 \\
defilement on the girl child? & Teenage pregnancy & 98 & 24.5 \\
& Psychological imbalance & 141 & 35.3 \\
& Spread of HIV/AIDS and STIs & 106 & 26.5 \\
\hline Total & & $\mathbf{4 0 0}$ & $\mathbf{1 0 0}$ \\
\hline
\end{tabular}

Source: Field work, 2021

The table 3 above shows the results of the effect of defilement of the girl child in Ugbighokho Community. Two salient questions were raised to elicit response from the respondents. Question on whether female defilement have any negative effect on the girl child. In a total of 400 respondents, $293(73.3 \%)$ agreed that female defilement have negative effect on the girl child, $33(8.3 \%)$ disagreed that female defilement have negative effects on the girl child in Ugbighokho Community while $74(18.5 \%)$ were undecided in their responses.

In finding out the negative effects of defilement on the girl child in Ugbighokho Community, out of 400 participants, $55(13.8 \%)$ stated that female child defilement causes traumatic experience to the girl child. $98(24.5 \%)$ stated that female child defilement causes teenage pregnancy to the girl child, $141(35.3 \%)$ stated that female child defilement causes psychological imbalance to the girl child and $106(26.5 \%)$ stated that female child defilement leads to the spread of HIV/AIDS and STIs to the girl child.

The above analyses were also affirmed by some participants in the focus group discussion (FGD) who reported as follow:

"Whenever I remember how my older nephew of about 23 years old always touched my sensitive parts and also slept with me when I was 15 years old whenever my uncle was not around. That incident disturbed me mentally and it even affected my academic performance during my secondary school education. At times, it makes me wants to even commit suicide, especially whenever I come in contact with anyone that behaves like him". (FGD 2/20 years old/Single/2021)

Another respondent has this to say;

"My neighbour's daughter was sexually abused before her thirteenth birthday, when her mother noticed the bruises on her vagina; she applied first aid by putting her in warm salt water to locally prevent the spread of STIs. I can confidently tell you that the little damsel has not gotten herself back because of the pains and traumatic experience she encountered after the inhumane act from her 


\section{defiler". (FGD 4/45 years/Married/Child Welfare Officer/2021)}

From the foregoing, it is evident that majority of the participants agreed that female defilement have serious adverse effect on the girl child. This may be due to the negative consequences suffered by the victims. The above finding conforms to the work of Gwitira (2015) who argues that the longterm consequences of child abuse are numerous. Studies have also shown that there are other negative consequences of defilement on the girl child as these can be linked with visual and hearing deficit, emotional disturbances and low self-esteem, aggressive tendencies and other psychological disorders.

\section{Conclusion and Recommendations}

Child sexual abuse is multifaceted; as it involves a situation where a child is sexually abused by either a close relative, caregiver (parents/guardian), those around her neighbourhood, strangers etc. Young females are made to sell sex in exchange for food, cash or favour as they are either been raped or sexually molested by individual such as an adult, a gang or maybe a peer living in the same community with the girl-child; groomed online by an older male and lured into sexual acts; exhibitionism; child pornography; or producing indecent images; trapped into sexual slavery by organized groups of child sex offenders; or raped by a combatant in the context of war. Conclusively, several factors such as lack of parental care, lack of finance or poverty, ignorance and the nature of the environment were vital factors that cause female defilement which in turns have negative effects on the lives of the victims in Ugbighokho Community.

This paper, therefore recommends that:

1. Poverty reduction programmes by the government in partnership with other relevant stakeholders such as the developmental partners should fight poverty by creating income generating activities that will help in preventing parents and guidance from accepting monetary settlement and being compromised in defilement cases of the girl-child for material gains from the offenders and their family members.

2. Parents should be more vigilant in fighting against defilement. This can be done by performing their responsibilities in providing for the needs of their children.

\section{References}

Abdulkadir, I., Musa, H.H, Umar, L.W, Musa, S, Jimoh, W.A \& Aliyu Na'uzo, M. (2011). “Child Sexual Abuse: A Review of Cases at General Hospital, Suleja, Niger State”, Nigeria Medical Journal (52) 2:15.

Adetayo, O. (2005). A Review of Rape Cases in Lagos State, The Punch, (Lagos, June 3, 2005) p. 359.

Agams, L. G. (2013). "Prosecuting Rape in Nigeria III - The Updates", This Day Newspaper, (Lagos, January 29, 2013) p. 11.

Biodun, O. (2010). "Knowledge and Perception of Child Sexual Abuse in Urban Nigeria: Some Evidence from a Community-Based Project", African Journal of Reproductive Health, (4)2:45.

Collin-Vezina, D., Daigneault, I., \& Hebert, M. (2013). Lessons learned from child sexual abuse research: prevalence, outcomes and preventive strategies. Child \& Adolescent Psychiatry \& Mental Health, 7(1):22. https://doi.org/10.1186/1753-200o-7-22

Criminal Code Act, Chapter 77, Laws of the Federation of Nigeria 1990. Retrieved 2 April 2016.

Constitution of the Federal Republic of Nigeria 1999 as amended (2011) CAP C23 LFN 2004

Folake, B. (2004) "Child Victim of Sexual Abuse in Nigeria", Frontiers of Legal Research, Vol. 2, No. 1, pp. 83-99.

Greco, D. \&Dawgert, S. (2007): Poverty and sexual violence: Building prevention and intervention responses. A guide for counselors and advocates. Pennsylvania Coalition Against Rape. http://www.pcar.org/sites/ default/files/pagespdf/poverty_and_sexual_violence.pdf

Gwitira, M. (2015). "Child Defilement in the Times of HIV and AIDS". UNICEF: Harare, Zimbawe. Available at: http://www.afcast.org.zw/index.php?option=com_ content\&view=article\&id=475: child-defilement-in-thetimes-of-hiv-and-aids-child-defilement-in-time-of-hiv-andaids\&catid=42: lectures\&Itemid $=293$ 
Heise L, Ellsberg M, Gottemoeller M. (2002). A global overview of gender-based violence. International Journal of Gynecology \& Obstetrics, 78(1) S5-S14 https://doi.org/10.1016/Soo20-7292(02)ooo38-3

Hillis, S., Mercy, J., Amobi, A., \& Kress, H. (2016). Global Prevalence of Past-year Violence Against Children: A Systematic Review and Minimum Estimates. Pediatrics, 137(3), e20154079. https://doi.org/10.1542/peds.20154079

Human Rights Council, (2013) Annual Report of the Special Representative of the Secretary-General on Violence against Children, A/HRC/22/55, United Nations, New York.

Ikechebelu, J. I. (2008). Sexual Abuse among Juvenile Female Street Hawkers in Anambra State, Nigeria”, African Journal of Reproductive Health, (12)1:111-119.

Kantrowitz, R.E \& Okun, B.F (2015). Effective Helping: Interviewing and Counseling Techniques

Langan, P. and Wolf, H. C. (2013), Child Rape Victims", Journal of Interpersonal Violence. (4) 1: $101-108$.

Madu, S.N, Ndom, R.E, \& Ramashia, C.L (2010). Depression among female survivors of domestic violence in thohoyandou, South Africa. https://doi:10.4314/gab.v8i1.54706

Nzewi, E. N. (2013). Street Hawking: An etiological Factor in the Sexual Abuse of Children”, Clinical Psychology Review. (21) 1:134-141.

Pinheiro, P. (2006). World Report on Violence Against Children. New York: United Nations Secretary General's Study on Violence Against Children. Accessed at https://www.unicef.org/violencestudy/

Schwartz-Kennery, B.M., McCauley, M.; and Epstein, M. (2001). Child Abuse: a Global View. Wesport, CT: Greenwood.

Sumner, S.A., Mercy, A.A., Saul, J., Motsa-Nzuza, N., Kwesigabo, G., Buluma, R., Marcelin, L.H., Lina, H., Shawa, M., Moloney-Kitts, M., Kilbane, T., Sommarin, C., Ligiero, D.P., Brookmeyer, K., Chiang, L., Lea, V., Lee, J., Kress, H., Hillis, S.D., \& Centers for Disease Control and Prevalence (CDC) (2015). Prevalence of sexual violence against children and use of social services- seven counries, 2007-2013. MMWR. Morbidity and mortality weekly report, 64(21), 565-569.

Terry, J. K. \& Tallon, J. (2010) Child Sexual Abuse: A review of the literature. The John JayCollege. New York.

Tukur, J., Omale, E. A. \& Abubakar, I. S. (2007). Increasing Incidence of Sexual Abuse on Children: Report from a Tertiary Health Facility in Kano", Journal of Medicine and Rehabilitation, (1)1:19-21.

UNICEF, (2015). The State of the World's Children, New York: UNICEF.

United Nations, (2008). Good practices in legislation on violence against women. Accessible at https://www.un.org/womenwatch/daw/egm/vaw_legislation_2008/Report\%2oEGMGPLVAW\%20(final\%201 1.11.08).pdf

Wilson, K. \& Ryan, V. (2006). Play Therapy: A Non-Directive Approach for Child and Adolescents. Elsevier Health Science, Jessica Kingsley Publishers.

WHO, (1999) Report of the Consultation on Child Abuse and Prevention, (Geneva: WHO)

WHO, (2002). Sexual violence: World report on violence and health. http://www.who.int/violence_injury_ prevention/violence/global_campaign/en/chap6.pdf.

WHO, (2014). Global status report on violence prevention 2014, World Health Organization, Geneva. http//www.who.int/violence_injury_prevention/violence/status_report/2014/en/ (accessed July $24,2021$. 